\title{
ALAT TULANG DARI SITUS SANGIRAN (Bone Tools From Sangiran Site)
}

\author{
Ilham Abdullah \\ Balai Pelestarian Situs Manusia Purba Sangiran \\ ilhamabdullah9969@gmail.com
}

\begin{abstract}
Some of bone tools from Sangiran Site have been published through reports, scientific articles, and thesis. However, they have not been analyzed deeply. This paper provides conclusion and information about all bone tools finding in Sangiran both those that are new and that have been published previously. There are 33 bone tools identified namely from cervus sp., cervushippelaphus, sus sp., bos $s p$., rhinoceros, elephantidae, andbovidae. The technics used are fracturing, cropping, splitting, pressing, and rubbing. Those processes create blade, point, and spatula. Bone tools appeared firstly in Sangiran around 900.000 years ago until 100.000 years ago. They were found in Ngebung, Cangkol, GrogolanWetanManyarejo, and Dayu.
\end{abstract}

Keywords: Sangiran Site, bone tools, raw materials, technology, tipology, cronology, distributions

\section{ABSTRAK}

Beberapa alat tulang dari Situs Sangiran telah dipublikasikan melalui laporan penelitian, artikel ilmiah, dan skripsi, tetapi belum dibahas mendalam. Tulisan ini merangkum dan menginformasikan semua temuan alat tulang dari Situs Sangiran yang telah terpublikasi sebelumnya beserta beberapa temuan baru. Alat tulang temuan dari Situs Sangiran berhasil diidentifikasi, terdapat 12 jenis komponen anatomis binatang yang digunakan sebagai alat, binatang yang tulangnya digunakan sebagai alat tulang adalah cervus sp., cervus hippelaphus, sus sp., bos sp., rhinoceros, elephantidae, dan bovidae. Teknik yang digunakan dalam membuat alat tulang adalah teknik pecah, teknik pangkas, teknik belah, teknik tekan, dan teknik gosok. Jenis alat tulang yang dihasilkan adalah pisau, lancipan, dan spatula. Alat tulang di Situs Sangiran muncul pertama kali pada sekitar 900.000 tahun yang lalu dan eksis hingga sekitar 100.000 tahun lalu. Ditemukan di sekitar Desa Ngebung, Cangkol, Grogolan Wetan Desa Manyarejo, dan di sekitar Desa Dayu.

Kata kunci: Situs Sangiran, alat tulang, bahan baku, teknologi, tipologi, kronologi, sebaran

Tanggal masuk : 8 September 2014

Tanggal diterima : 3 November 2014 


\section{PENDAHULUAN}

Situs Sangiran merupakan salah satu situs prasejarah terpenting di Indonesia. Situs Sangiran tak hentihentinya memunculkan data baru tentang kehidupan manusia purba, binatang, dan lingkungannya dari periode Pleistosen di Pulau Jawa. Situs Sangiran menempati areal seluas $\pm 56 \mathrm{~km}^{2}$ yang termasuk dalam wilayah administratif Kabupaten Sragen dan Kabupaten Karanganyar, Provinsi Jawa Tengah. Wilayah Kabupaten Sragen yang masuk ke dalam kawasan situs adalah Kecamatan Kalijambe, Kecamatan Plupuh, dan Kecamatan Gemolong. Sedang wilayah Kabupaten Karanganyar yang masuk dalam kawasan situs adalah wilayah Kecamatan Gondangrejo (Yuwono, 2009:13-14).

Singkapan alamiah berbagai jenis lapisan tanah di Situs Sangiran mampu menggambarkan kronologi perubahan lingkungan beserta kehidupan manusia, flora dan fauna pada masanya, dimulai ketika lokasi ini berupa lingkungan laut pada sekitar 2,4 juta tahun lalu hingga 1,8 juta tahun lalu, yang dibentuk oleh endapan lempung biru dan mengandung berbagai jenis fosil moluska laut, gigi ikan hiu, kepiting, penyu, dan foraminifera dikenal dengan sebutan Formasi Kalibeng. Kemudian di atasnya diendapkan Formasi Pucangan yang terbentuk sekitar $1,8 \mathrm{~s} / \mathrm{d} \quad 0,9$ juta tahun lalu berupa endapan breksi laharik di bagian bawah dan lempung hitam di bagian atas yang mencirikan lingkungan rawa mengandung temuan berupa fosil buaya, kura-kura, moluska air tawar, berbagai binatang vertebrata, berbagai jenis tumbuhan dan kelompok Homo erectus arkaik, serta alat batu berupa alat serpih. Selanjutnya pada sekitar 900.000 tahun lalu hingga sekitar 250.000 tahun lalu mulai terbentuk lingkungan daratan ditandai oleh endapan gamping pisoid dan kongkresi konglomeratan dikenal dengan sebutan lapisan Grenzbank, kemudian di atasnya terendapkan lapisan pasir fluvio-volkanik anggota Formasi Kabuh, pada kedua lapisan ini mengandung temuan berupa fosil kelompok Homo erectus tipik, alat serpih, bola batu, berbagai tipe kapak batu, binatang vertebrata, moluska air tawar, dan tumbuhan. Kemudian di atasnya terendapkan breksi laharik disusul pasir fluvio-volkanik anggota Formasi Notopuro yang terbentuk sekitar 250.000 hingga 100.000 tahun lalu, pada lapisan ini mengandung fosil binatang vertebrata, tumbuhan, bola batu, berbagai tipe alat masif dan berbagai tipe alat serpih (Widianto dan Simanjuntak, 2009 : 60-63).

Situs Sangirantelahmenghasilkan lebih dari 100 individu Homo erectus, jumlah itu lebih dari $50 \%$ temuan fosil Homo erectus di dunia dan $70 \%$ di Indonesia. Temuan binatangnya sangat melimpah, semua kelompok fauna di Jawa terdapat di Sangiran. Peralatan mereka terbuat dari batu, sebagian berupa alat masif dan sebagian lagi berupa alat serpih. Alat serpih sudah diakui sebagai buatan mereka "The Sangiran Flakes Industry", sebagian alat serpih tersebut merupakan alat yang berumur paling tua di Indonesia. Alat batu tersebar di beberapa lokasi di dalam Kawasan Situs Sangiran dan menempati lapisan waktu dimulai dari yang tertua di Pucangan hingga yang termuda di Notopuro (Widianto dan Simanjuntak, 2009).

Peralatan yang terbuat dari bahan lainkemungkinanjugamerekagunakan, misalnya komponen tumbuhan dan komponen tulang binatang. Selama ini banyak peneliti yang beranggapan bahwa sulit menemukan alat tulang, kayu, dan bambu (berbahan organik) di Situs Sangiran, karena kalaupun terkonservasi dengan baik atau menjadi fosil, maka artefak tersebut pasti sulit untuk dikenali. Hal tersebut 
diakibatkan oleh tingkat pembundaran, pengelupasan, dan patinasi di Situs Sangiran sangat tinggi sehingga jejak teknologi yang terdapat pada fosil alat tulang akan mengalami kerusakan atau tidak nampak.

Keberadaan alat tulang di Situs Sangiran telah dipublikasikan oleh para peneliti, namun belum mendapatkan perhatian khusus. Kemungkinan jumlahnya yang masih sedikit dan publikasi itu terpisah secara sendirisendiri serta antara peneliti tidak terjadi komunikasi. Data publikasi temuan alat tulang di Situs Sangiran telah menyebutkan lebih dari 7 buah alat tulang, penemuan tahun 1995 sampai tahun 2011. Penelitian tentang alat tulang di Situs Sangiran telah dilakukan oleh Metta A.P.S pada tahun 2012, hasil penelitiannya berupa skripsi berjudul "Bentuk Bidang Pecahan Fosil Cervidae Koleksi Museum Sangiran (Analisis Mikroskopis)". Metta berhasil mengidentifikasi 8 diantara 59 sampel spesimen fosil cervidae sebagai alat tulang melalui pengamatan mikroskop. Temuan alat tulang bertambah setelah seorang penduduk menyerahkan temuan berupa 7 buah alat tulang pada tahun 2012. Jumlah tersebut bertambah lagi setelah ditemukannya 1 buah alat tulang pada saat kami melakukan registrasi dan inventarisasi koleksi di Gudang BPSMP Sangiran. Terakhir adalah penemuan dua buah alat tulang dari kotak ekskavasi di Ngebung pada tahun 2013.

Berdasarkan catatan penemuan dan koleksi alat tulang yang berasal dari Situs Sangiran, maka penulis mencoba untuk merangkum dan mengkomunikasikan temuan alat tulang tersebut. Walaupun jumlahnya masih sedikit, penulis telah mempublikasikan temuan alat tulang dari Situs Sangiran sebanyak 25 buah, alat tulang tersebut memberikan informasi bahwa Homo erectus di Situs Sangiran telah membuat dan memakai alat tulang sejak sekitar 900.000 tahun yang lalu hingga sekitar 100.000 tahun yang lalu. Mereka menggunakan teknik pecah, teknik pangkas, teknik belah, dan penggosokan, serta gabungan teknik-teknik itu dalam membuat alat tulang. Alat yang mereka buat terdiri atas pisau, spatula, lancipan, dan variasi lancipan yaitu lancipan berujung ganda. Bahan baku yang digunakan terdiri atas 10 jenis komponen anatomis binatang yaitu: 1 . tulang kering (tibia), 2. tulang lengan atas (humerus), 3. tulang paha (femur), 4. tanduk (antler), 5. telapak kaki depan (metacarpal), 6. tulang hasta (radius), 7 . tulang rusuk (costae), 8. tulang panjang, 9. tulang kaki, dan 10. tulang binatang. Jenis binatang yang tulangnya digunakan sebagai bahan pembuatan alat tulang adalah cervus sp. (rusa), cervus hippelaphus (rusa), sus sp. (babi), bos sp. (banteng), rhinoceros (badak), elephantidae (gajah), dan bovidae (keluarga Banteng, Sapi, Kerbau). Alat tulang di Situs Sangiran ditemukan di sekitar Desa Ngebung (Ngebung, Gunung Kelir Padas, Sendang Klampok, Triangulasi, Grasak), Desa Cangkol (Blimbing dan Tapan), Desa Manyarejo (Grogolan Wetan), Desa Dayu yaitu di Situs Tanjung, Dayu, dan Pucung (Abdullah, 2013: 6581). Walaupun jumlah masih terbatas yaitu sekitar 34 spesimen, tulisan ini berusaha memberikan informasi di Situs Sangiran terdapat alat tulang.

Tulisan ini akan membahas yang terkait dengan bahan baku yaitu jenis bintang dan bagian tulang yang digunakan sebagai alat. Teknologi yaitu teknik yang digunakan dalam pembuatan alat tulang.Tipologi yaitu bentuk umum, letak tajaman, dan jejak pakai alat tulang. Kronologi yaitu umur alat tulang berdasarkan lapisan tanah tempat penemuannya, dan sebaran yaitu lokasi penemuan masing-masing alat tulang di Situs Sangiran. 
Alat tulang dari Situs Sangiran

Sampai saat ini, terdapat lebih dari 34 spesimen alat tulang dari
Situs Sangiran. spesimen tersebut penulis dapatkan melalui pencarian data pustaka dan identifikasi terhadap koleksi temuan BPSMP Sangiran.

\section{Tabel 1. Alat Tulang Situs Sangiran}

\begin{tabular}{|c|c|c|c|c|c|}
\hline No & Komponen anatomis & $\begin{array}{c}\text { Teknik } \\
\text { Pembuatan }\end{array}$ & $\begin{array}{l}\text { Jenis dan Jejak } \\
\text { Pemakaian }\end{array}$ & Lokasi temuan & Lapisan/ Usia \\
\hline 1 & $\begin{array}{l}\text { tulang kering (tibia) } \\
\text { bovidae }\end{array}$ & - & - & $\begin{array}{l}\text { Gunung Kelir, Padas, } \\
\text { Ngebung, Kalijambe }\end{array}$ & Notopuro/ Pleistosen Atas \\
\hline 2 & tulang binatang & - & - & Dayu, Gondangrejo & Kabuh/ Pleistosen Tengah \\
\hline 3 & - & - & - & Dayu, Gondangrejo & Grenzbank/Pleistosen Tengah \\
\hline 4 & $\begin{array}{l}\text { tulang rusuk (costae) } \\
\text { elephantidae (gajah) }\end{array}$ & $\begin{array}{l}\text { pecah, pangkas, } \\
\text { dan gosok }\end{array}$ & $\begin{array}{l}\text { pisau, tidak ada } \\
\text { jejak }\end{array}$ & $\begin{array}{l}\text { Blimbing, Cangkol, } \\
\text { Kalijambe, Sragen }\end{array}$ & - \\
\hline 5 & $\begin{array}{l}\text { telapak kaki depan } \\
\text { (metacarpal) rhinoceros } \\
\text { (badak) }\end{array}$ & $\begin{array}{l}\text { pangkas dan } \\
\text { gosok }\end{array}$ & $\begin{array}{l}\text { lancipan, tidak ada } \\
\text { jejak }\end{array}$ & $\begin{array}{l}\text { Tapan, Cangkol, } \\
\text { Kalijambe, Sragen }\end{array}$ & - \\
\hline 6 & $\begin{array}{l}\text { lengan atas (humerus) } \\
\text { bibos palaeosondaicus } \\
\text { (banteng) }\end{array}$ & $\begin{array}{l}\text { pecah dan } \\
\text { pangkas }\end{array}$ & $\begin{array}{l}\text { lancipan, tidak ada } \\
\text { jejak }\end{array}$ & $\begin{array}{l}\text { K.9 Grogolan Wetan, } \\
\text { Manyarejo, Plupuh, } \\
\text { Sragen }\end{array}$ & Kabuh/ Pleistosen Tengah \\
\hline 7 & $\begin{array}{l}\text { telapak kaki depan } \\
\text { (metacarpal) bos sp. } \\
\text { (sapi) }\end{array}$ & $\begin{array}{l}\text { pecah dan } \\
\text { pangkas }\end{array}$ & $\begin{array}{l}\text { lancipan, tidak ada } \\
\text { jejak }\end{array}$ & $\begin{array}{l}\text { Ekskavasi, Tanjung, } \\
\text { Dayu, Gondangrejo }\end{array}$ & grenzbank/ Pleistosen Tengah \\
\hline 8 & $\begin{array}{l}\text { tulang kering (tibia) bos } \\
\text { sp. (sapi) }\end{array}$ & $\begin{array}{l}\text { pecah, pangkas, } \\
\text { dan penggosakan }\end{array}$ & lancipan, terpakai & - & Kabuh /Pleistosen Tengah \\
\hline 9 & $\begin{array}{l}\text { paha (femur) cervus } \\
s p \text {. (rusa) }\end{array}$ & \begin{tabular}{|l|} 
pecah dan \\
pangkasan
\end{tabular} & $\begin{array}{l}\text { lancipan, tidak ada } \\
\text { jejak }\end{array}$ & - & Kabuh/ Pleistosen Tengah \\
\hline 10 & $\begin{array}{l}\text { lengan atas (humerus) } \\
\text { cervus sp. (rusa) }\end{array}$ & $\begin{array}{l}\text { pecah dan } \\
\text { pangkasan }\end{array}$ & $\begin{array}{l}\text { lancipan, tidak ada } \\
\text { jejak }\end{array}$ & - & Kabuh/ Pleistosen Tengah \\
\hline 11 & $\begin{array}{l}\text { tulang kering (tibia) } \\
\text { cervus sp. (rusa) }\end{array}$ & $\begin{array}{l}\text { pecah dan } \\
\text { pangkasan }\end{array}$ & $\begin{array}{l}\text { lancipan, tidak ada } \\
\text { jejak }\end{array}$ & - & Kabuh/ Pleistosen Tengah \\
\hline 12 & $\begin{array}{l}\text { tanduk (antler) cervus } \\
\text { sp. (rusa) }\end{array}$ & Pangkas & $\begin{array}{l}\text { lancipan, tidak ada } \\
\text { jejak }\end{array}$ & - & Kabuh/ Pleistosen Tengah \\
\hline 13 & $\begin{array}{l}\text { tanduk (antler) cervus } \\
\text { hippelaphus (rusa) }\end{array}$ & pangkas & lancipan, terpakai & - & Kabuh/ Pleistosen Tengah \\
\hline 14 & $\begin{array}{l}\text { tanduk (antler) cervus } \\
\text { sp. (rusa) }\end{array}$ & pecah dan pankas & $\begin{array}{l}\text { lancipan, tidak ada } \\
\text { jejak }\end{array}$ & - & Kabuh/ Pleistosen Tengah \\
\hline 15 & $\begin{array}{l}\text { tanduk (antler) cervus } \\
\text { sp. (rusa) }\end{array}$ & $\begin{array}{l}\text { pecah dan } \\
\text { pangkas }\end{array}$ & $\begin{array}{l}\text { lancipan, tidak ada } \\
\text { jejak }\end{array}$ & - & Kabuh/ Plestosen Tengah \\
\hline 16 & $\begin{array}{l}\text { tanduk (antler) cervus } \\
\text { sp. (rusa) }\end{array}$ & Pangkas & $\begin{array}{l}\text { lancipan, tidak ada } \\
\text { jejak }\end{array}$ & - & Kabuh /Pleistosen Tengah \\
\hline 17 & $\begin{array}{l}\text { tanduk (antler) cervus } \\
\text { sp. (rusa) }\end{array}$ & $\begin{array}{l}\text { pecah dan } \\
\text { pangkas }\end{array}$ & $\begin{array}{l}\text { spatula, tidak ada } \\
\text { jejak pakai }\end{array}$ & $\begin{array}{l}\text { Pucung, Dayu, } \\
\text { Gondangrejo, } \\
\text { Karanganyar } \\
\end{array}$ & Kabuh/ Pleistosen Tengah \\
\hline 18 & $\begin{array}{l}\text { lengan atas (humerus) } \\
\text { sus sp. (babi) }\end{array}$ & $\begin{array}{l}\text { pecah dan } \\
\text { pangkas }\end{array}$ & $\begin{array}{l}\text { spatula, tidak ada } \\
\text { jejak pakai }\end{array}$ & $\begin{array}{l}\text { Pucung, Dayu, } \\
\text { Gondangrejo, } \\
\text { Karanganyar }\end{array}$ & Kabuh/ Pleistosen Tengah \\
\hline 19 & $\begin{array}{l}\text { tulang kering (tibia) } \\
\text { bovidae (famili sapi, } \\
\text { kerbau) }\end{array}$ & $\begin{array}{l}\text { pecah dan } \\
\text { pangkas }\end{array}$ & $\begin{array}{l}\text { spatula, tidak ada } \\
\text { jejak pakai }\end{array}$ & $\begin{array}{l}\text { Sendang Klampok, } \\
\text { Ngebung, Kalijambe, } \\
\text { Sragen }\end{array}$ & Kabuh/ Pleistosen Tengah \\
\hline 20 & $\begin{array}{l}\text { tulang hasta (radius) } \\
\text { bovidae (famili sapi, } \\
\text { kerbau) }\end{array}$ & $\begin{array}{l}\text { pecah dan } \\
\text { pangkas }\end{array}$ & $\begin{array}{l}\text { lancipan, tidak ada } \\
\text { jejak }\end{array}$ & $\begin{array}{l}\text { Triangulasi, Ngebung, } \\
\text { Kalijambe, Sragen }\end{array}$ & 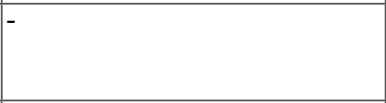 \\
\hline 21 & tulang kaki bovidae & $\begin{array}{l}\text { pecah, pangkas, } \\
\text { belah, dan gosok? }\end{array}$ & $\begin{array}{l}\text { spatula/pisau, } \\
\text { terpakai }\end{array}$ & Ngebung, Kalijambe & Kabuh/ Pleistosen Tengah \\
\hline 22 & $\begin{array}{l}\text { telapak kaki depan } \\
\text { (metacarpal) bovidae }\end{array}$ & $\begin{array}{l}\text { pecah dan } \\
\text { pangkas }\end{array}$ & $\begin{array}{l}\text { spatula, tidak ada } \\
\text { jejak pakai }\end{array}$ & $\begin{array}{l}\text { Triangulasi, Ngebung, } \\
\text { Kalijambe, Sragen }\end{array}$ & - \\
\hline 23 & $\begin{array}{l}\text { tulang hasta (radius) } \\
\text { bovidae (famili sapi, } \\
\text { kerbau) }\end{array}$ & $\begin{array}{l}\text { pecah dan } \\
\text { pangkas }\end{array}$ & $\begin{array}{l}\text { lancipan, tidak ada } \\
\text { jejak }\end{array}$ & $\begin{array}{l}\text { Ngebung, Kalijambe, } \\
\text { Sragen }\end{array}$ & 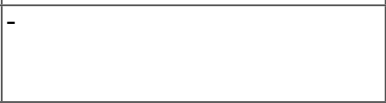 \\
\hline 24 & tulang panjang bovidae & $\begin{array}{l}\text { pecah, pangkas, } \\
\text { belah, dan gosok? }\end{array}$ & $\begin{array}{l}\text { spatula, tidak ada } \\
\text { jejak pakai }\end{array}$ & $\begin{array}{l}\text { TP. } 2 \text { 2013, Klaster } \\
\text { Ngebung, Kalijambe, } \\
\text { Sragen }\end{array}$ & Kabuh/ Pleistosen Tengah \\
\hline 25 & tulang kaki bovidae & $\begin{array}{l}\text { pecah, tekan, } \\
\text { pangkas, dan } \\
\text { gosok? }\end{array}$ & lancipan, terpakai & $\begin{array}{l}\text { TP. } 2 \text { 2013, Klaster } \\
\text { Ngebung, Kalijambe, } \\
\text { Sragen }\end{array}$ & Kabuh/ Pleistosen Tengah \\
\hline
\end{tabular}

Sumber: BPSMP Sangiran 
Alat tulang nomor 26 berupa kapak perimbas (chopper) yang terbuat dari gading (tusk) Stegodon pada formasi Kabuh berumur 800000 BP yang ditemukan di Bukit Ngebung dalam ekskavasi oleh tim IndonesiaPerancis tahun 1980-an (Anonim, 2013:102). Tempat konservasi spesimen ini tidak diketahui, sehingga penulis tidak melakukan deskripsi teknologi pembuatan dan pengukuran.

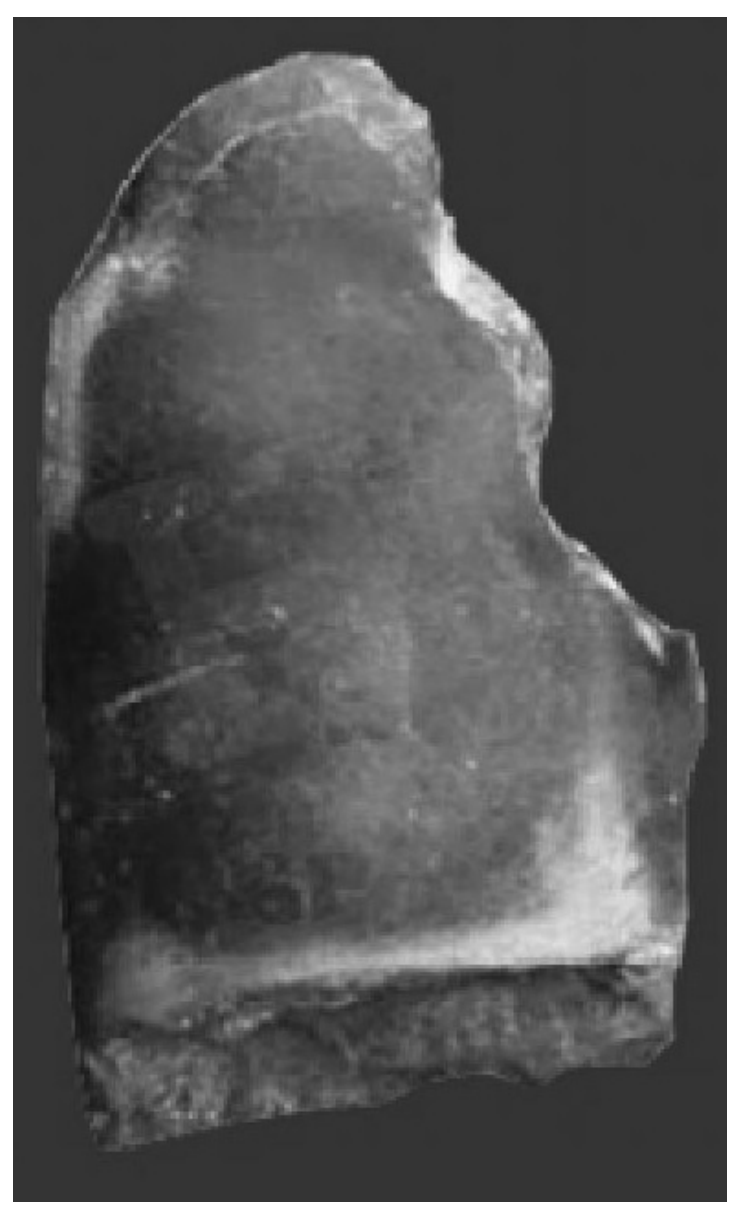

Gambar 1. Alat Tulang No. 26 Kapak Perimbas terbuat dari Gading Gajah (dokumentasi BPSMP Sangiran)

Alat tulang nomor 27 sampai dengan nomor 34 merupakan koleksi BPSMP Sangiran yang berasal dari laporan temuan masyarakat. Alat tulang nomor 27 berupa lancipan terbuat dari fragmen tulang telapak kaki (distal metatarsal) bovidae. Ditemukan di sekitar Grogolan Wetan, dan Manyarejo. Lokasi tepat penemuan tidak diketahui, namun berdasarkan pasir kasar berwarna hitam abu-abu yang terdapat pada rongga bekas pangkasan maka alat ini pernah terendapkan pada formasi Kabuh atau Notopuro. Tulang utuh dipecah menjadi dua bagian yang menghasilkan potongan bagian distal dengan ukuran panjang 160, $56 \mathrm{~mm}$, lebar 64, $87 \mathrm{~mm}$, dan tebal 40, $28 \mathrm{~mm}$. Sebuah titik pukul terlihat pada bagian diaphisys tulang yang menghasilkan pangkasan mengarah ke ujung dan ke arah caudal (bagian belakang tulang) sehingga menghasilkan bentuk pecahan spiral dengan panjang pecahan 77, $29 \mathrm{~mm}$, dan dengan sudut kemiringan pangkasan sebesar $30^{\circ}$. Terdapat pecahan pada bagian ujung lateral sisi cranial dengan warna yang berbeda dibandingkan dengan warna permukaan tulang, panjang pecahan ini adalah 20,07 mm. Hal tersebut menjelaskan bahwa pecahan pada bagian ujung tersebut terbentuk setelah tulang terangkat dari matriksnya.

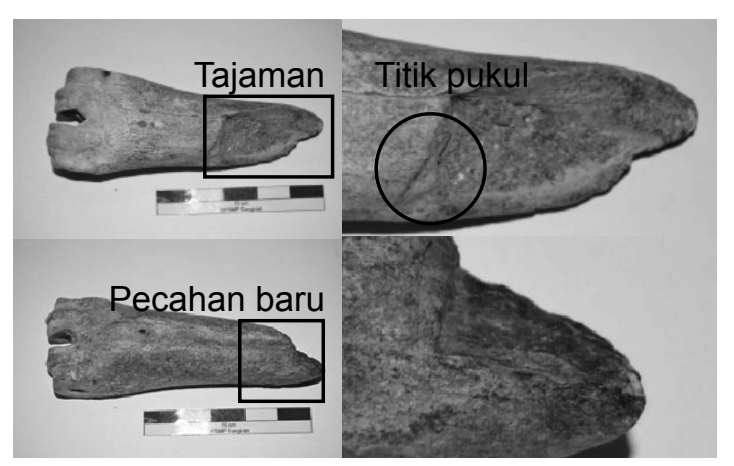

Gambar 2. Alat tulang no. 27 lancipan terbuat dari tulang kaki bovidae (dokumentasi BPSMP Sangiran)

Alat tulang nomor 28 berupa lancipan terbuat dari tulang kering (tibia) bovidae. Telah diregistrasi dengan nomor 1007. Ditemukan di sekitar Sendangklampok. Lokasi tepat penemuan tidak diketahui. Tulang ini memiliki panjang 187, $02 \mathrm{~mm}$, lebar 54, $07 \mathrm{~mm}$, dan tebal 29, $30 \mathrm{~mm}$. Lancipan ini terbuat dari bagian atas 
(proximal) tibia sebelah kanan (dextra). Bekas pangkasan pembuatan tajaman terlihat pada kedua ujungnya (proximal dan distalnya). Tidak terlihat titik pukul pada pangkal pecahan karena setelah pemangkasan pembuatan tajaman, telah dilakukan pangkasan yang membelah alat ini menjadi dua bagian dari arah proximal menuju distal atau sebaliknya. Sepertinya titik pukul pada pangkasan ini ikut terlepas. Bekas pembelahan terlihat di bagian dorsal. Kemiringan sudut tajaman proximal sekitar $45^{\circ}$, sedangkan kemiringan sudut pada tajaman pada bagian distal adalah $30^{\circ}$.

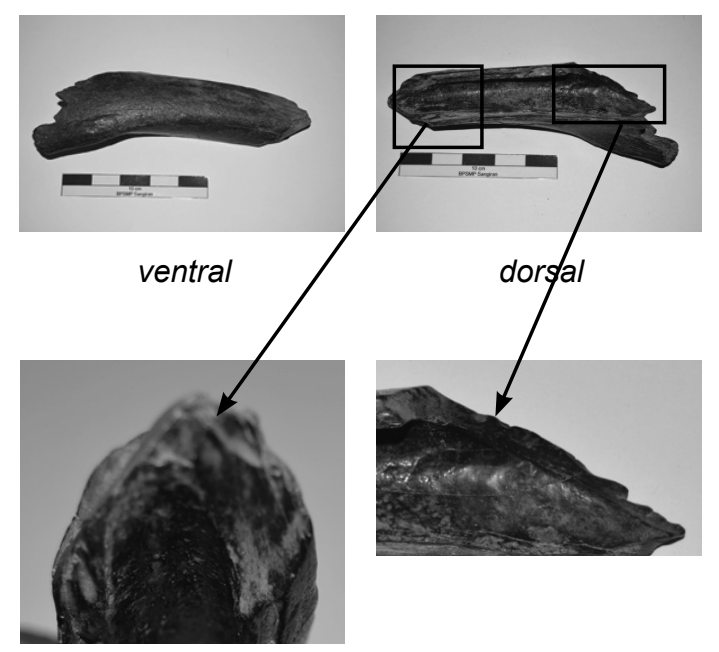

Tajaman pada disttal

Tajaman pada proximal

Gambar 3. Alat tulang no. 28, lancipan tulang kering bovidae (dokumentasi BPSMP Sangiran)

Alat tulang nomor 29 berupa lancipan terbuat dari fragmen tanduk (antler) rusa (cervidae). Telah diregistrasi dengan nomor 1008. Ditemukan di sekitar Sendangklampok, Desa Ngebung, Kecamatan Kalijambe, Kabupaten Sragen. Lokasi tepat penemuan tidak diketahui. Tulang ini memiliki panjang 144, $71 \mathrm{~mm}$ dan diameter 42, $21 \mathrm{~mm}$. sebuah titik pukul terdapat pada bagian gagang (proximal) alat, merupakan bekas pemangkasan untuk memotong bagian tanduk menjadi 2 bagian. Titik pukul berikutnya terlihat pada bagian dorsal alat yaitu bekas pemangkasan pembentukan tajaman dipangkas dari arah panggkal kearah ujung dengan panjang tajaman $97,73 \mathrm{~mm}$ dan sudut kemiringan $25^{\circ}$.

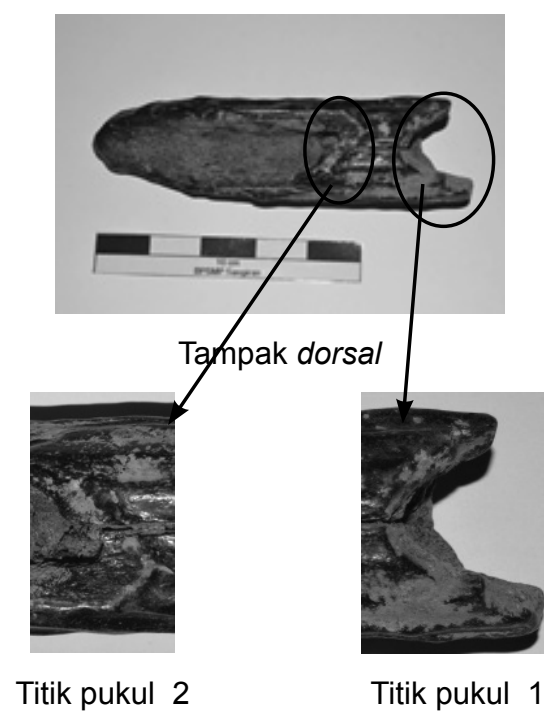

Gambar 4. Alat tulang no. 29, lancipan tanduk rusa (dokumentasi BPSMP Sangiran)

Alat tulang no.30 berupa spatula terbuat dari tulang kaki mamalia. Telah diregistrasi dengan nomor 1009. Ditemukan di tebing Sungai Brangkal, Desa Ngebung. Lokasi tepat penemuan tidak diketahui. Tulang ini memiliki panjang $91,74 \mathrm{~mm}$, lebar 49, $69 \mathrm{~mm}$, dan tebal 19, $72 \mathrm{~mm}$. Artefak ini dibentuk dari sebuah serpihan tulang kaki, proses pembuatannya dimulai dengan memangkas tulang utuh menjadi dua bagian dengan sebuah titik pukul pada bagian pangkal di sisi kortikal (dorsal). Pengerjaan berikutnya adalah pembuatan tajaman dengan pangkasan miring pada menuju ujung distal, kemudian pangkasan secara vertikal pada batang tulang sehingga menghasilkan tulang pipih dan melebar, pangkasan ini menghilangkan titik pukul pada pembuatan tajaman sebelumnya. 


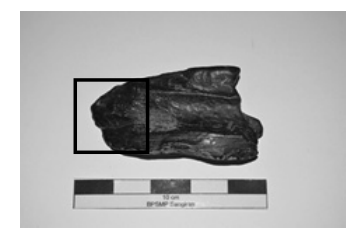

Tajaman
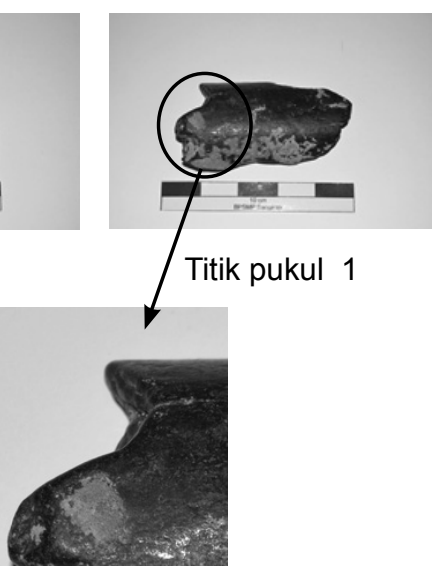

Gambar 5. Alat tulang no. 30 spatula tulang kaki mamalia (dokumentasi BPSMP Sangiran)

Alat tulang no. 31 berupa pisau terbuat dari tulang kaki mamalia. Telah diregistrasi dengan nomor 1010. Ditemukan di sekitar Dusun Wonolelo. Lokasi tepat penemuan tidak diketahui. Tulang ini memiliki panjang 83, 94 $\mathrm{mm}$, lebar 36, $97 \mathrm{~mm}$, dan tebal 20, $27 \mathrm{~mm}$. Artefak ini berbentuk pipih, tipis dan melebar dengan kondisi yang sangat membundar (rounded). Ciri yang terlihat pada artefak ini hanyalah morfologinya yang tipis dan kilapan di sepanjang sisi lateral kiri dan kanan pada sisi ventralnya. Pecahan yang terdapat di bagian distal lateral kiri memiliki sisi yang tipis dan diduga sebagai tajaman.
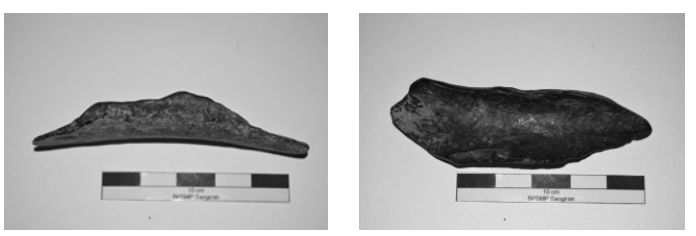

Tampak samping

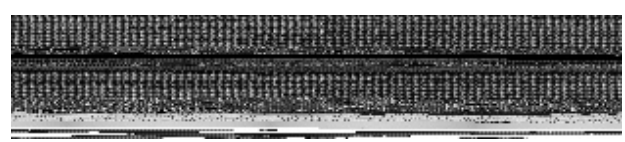

Tajaman

Gambar 6. Alat tulang no. 31, pisau tulang kaki mamalia (dokumentasi BPSMP Sangiran)

Alat tulang nomor 32 berupa lancipan terbuat dari tulang telapak kaki (proximal metarsal) bovidae. Alat tulang ini telah diregistrasi dengan nomor 1012. Ditemukan di Sungai Brangkal, Desa Ngebung, Kecamatan Kalijambe, Kabupaten Sragen. Lokasi tepat penemuan tidak diketahui. Alat tulang ini memiliki panjang 131,74 $\mathrm{mm}$, lebar 70, $50 \mathrm{~mm}$, tebal 23, 69 $\mathrm{mm}$. Pecahan yang dianggap sebagai tajaman sepanjang 68, $22 \mathrm{~mm}$ terlihat pada bagian sisi cranial (bagian depan tulang) dengan sudut kemiringan $45^{\circ}$, tidak terlihat titik pukul pada sekeliling pinggiran pecahan. Sebuah titik pukul terlihat pada bagian caudal (bagian belakang tulang) yang merupakan jejak pemangkasan untuk membagi dua tulang.
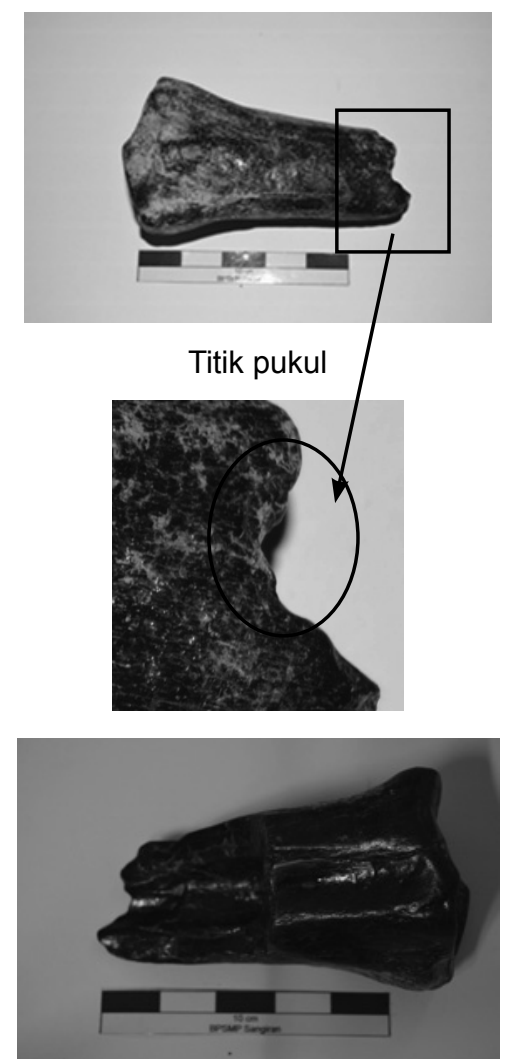

Tajaman

Gambar 7. Alat tulang no. 32, lancipan tulang kering bovidae (dokumentasi BPSMP Sangiran)

Alat tulang no. 33 berupa spatula terbuat dari tulang paha depan/lengan atas (distal humerus) bovidae. Telah diregistrasi dengan nomor 1013. Ditemukan sekitar Bukit Ngebung, Desa 
Ngebung. Lokasi tepat penemuan tidak diketahui. Spatula ini memiliki panjang $158,71 \mathrm{~mm}$, lebar $59,42 \mathrm{~mm}$, dan tebal 23,69 mm. Spatula ini memperlihatkan jejak pangkasan pembuatan tajaman yang terlihat pada kedua ujungnya distalnya. Tidak terlihat titik pukul pada bekas pecahan pembuatan tajaman karena telah dilakukan pemangkasan yang dilakukan searah panjang alat dari arah proximal ke arah distal atau tajaman yang membelah alat ini menjadi 2 bagian yang mengakibatkan titik pukul pembuatan tajaman ikut terlepas. Bekas pembelahan terlihat di bagian dorsal. Kemiringan sudut tajaman adalah sekitar $45^{\circ}$.

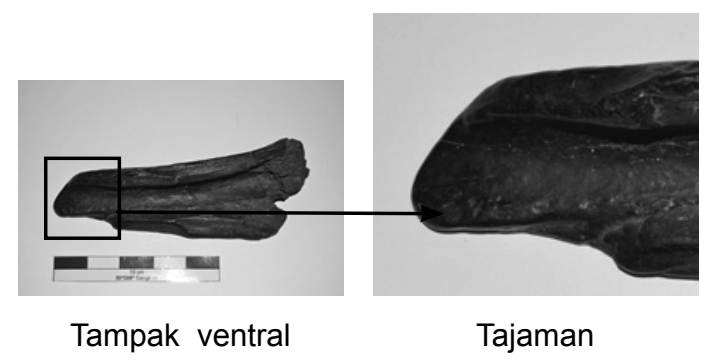

Gambar 8. Alat tulang no. 33. Spatula humerus bovidae (dokumentasi BPSMP Sangiran)

\section{Bahan baku}

Analisis taksonomi telah digunakan untuk mengetahui bagian tulang dan jenis bintang yang diamati. Pengamatan dilakukan secara makroskopis dengan menggunakan gambar/ foto dan fosil koleksi BPSMP Sangiran sebagai pembanding dan sebagai dasar penetapan bagian dan jenis binatang yang diamati. Berdasarkan literatur dan pengamatan/ identifikasi yang dilakukan terhadap 33 spesimen alat tulang dari Situs Sangiran, telah didapatkan sebanyak 12 jenis komponen tulang yang dijadikan bahan baku pembuatan alat tulang, beberapa diantaranya hanya diidentifikasi sebagai tulang binatang, tulang panjang, dan dua buah tulang kaki. Komponen tulang tersebut terdiri dari:
1. Tulang kering (tibia) sebanyak 5 buah 3 milik bovidae, sebuah milik bos sp. (sapi) dan satu lagi milik cervus sp. (rusa).

2. Tulang lengan atas (humerus) sebanyak 4 buah milik bibos palaesondaicus (banteng), cervus sp. (rusa), sus sp. (babi), dan bovidae.

3. Tulang paha (femur) cervus sp. (rusa).

4. Tanduk (antler) sebanyak 7 buah, 5 buah milik cervus sp., sebuah milik cervus hippelaphus (rusa), dan sebuah milik cervidae.

5. Telapak kaki depan (metacarpal) sebanyak 3 buah, milik rhinoceros (badak), bos sp. (sapi), dan bovidae.

6. Tulang hasta (radius) sebayak 2 buah milik bovidae.

7. Tulang rusuk (costae) milik elephantidae (gajah)

8. Tulang panjang bovidae.

9. Tulang kaki sebanyak 4 buah, 2 buah milik bovidae dan 2 buah milik mamalia.

10. Tulang binatang.

11. Telapak kaki belakang (metatarsal) sebanyak 2 buah milik bovidae.

12. Sebuah Gading (tusk/incisivus) milik gajah (elephantidae)

Komponen terbanyak adalah tanduk, tetapi secara umum lebih banyak bagian kaki. Terdapat sebuah komponen tulang rusuk (costae) dan sebuah gading gajah. Jenis binatang yang dipilih sebagai sebagai bahan baku pembuatan alat tulang oleh Homo erectus di Situs Sangiran yaitu: cervus sp., cervus hippelaphus, sus sp., bos sp., rhinoceros, elephantidae, dan bovidae.

\section{Teknologi alat tulang situs Sangiran}

Analisis teknologi pembuatan telah dilakukan untuk mengetahui teknik pembuatan artefak. Pengamatan dilakukan terhadap bentuk pecahan (frakturasi) dan jejak 
pemukulan. Pengamatan terhadap bentuk pecahan pada tulang dilakukan untuk membedakan antara tulang yang merupakan jejak akibat aktivitas manusia dengan yang bukan akibat dari aktivitas manusia. Tulang yang pecah akibat aktivitas manusia dipukul dengan alat atau benda lain, akan meninggalkan bekas pada titik pukul tulang tersebut. Karakteristik dari titik pemukulan adalah adanya wilayah pukul yang memiliki morfologi lekukan melingkar atau setengah lingkaran pada permukaan tulang dengan bentuk tepian bergerigi ataupun bertingkat namun tetap memiliki kesamaan dengan permukaan kortikalnya. Tulang yang dijadikan alat memiliki ciri-ciri yang terletak pada bagian tajaman, yaitu berkaitan dengan bentuk dan pembuatan tajaman. Jejak penajaman biasanya berupa striasi atau goresan yang berjajar di bagian tajaman dan kilapan akibat pengerjaan penghalusan. Beberapa teknik yang digunakan dalam pembuatan alat tulang diantaranya adalah teknik pangkas, teknik gosok, teknik pecah, dan teknik gabungan pangkas-gosok, serta gabungan lebih dari dua teknik. Analisis jejak pakai bertujuan untuk mengetahui apakah alat tersebut telah dipergunakan. Pengamatan dilakukan terhadap jejak pakai pada tajaman. Tulang yang dipakai atau digunakan akan meninggalkan jejak berupa retus pakai, goresan pada permukaan, kilapan, dan keausan pada tajaman (Lyman, 1994: 326 dalam Kusno, 2006:19).

Teknologi pembuatan alat tulang dari Situs Sangiran secara umum memperlihatkan penggabungan lebih dari satu teknik, dari 33 spesimen yang kami amati sebagian besar dibuat dengan teknik pecah lalu kemudian dilakukan pangkasan (pecah dan pangkas). Sebagian lagi ada yang memperlihatkan teknik gosok pada tahap akhir. Ada juga yang menggabungkan teknik tekan dan belah setelah pemecahan tulang. Berikut teknik yang digunakan dalam membuat alat tulang pada 25 spesimen yang penulis teliti, yaitu:

1. Pangkas: pangkasan terjal dilakukan terhadap tulang utuh untuk membagi dua tulang, bekas pangkasan digunakan sebagai tajaman. spesimen yang memperlihatkan teknik ini adalah nomor 12 dan nomor 13. Spesimen nomor 16 juga menggunakan teknik pangkasan karena memang merupakan ujung tanduk, jadi pemangkasan dilakukan hanya untuk membentuk tajaman.

2. Pecah dan pangkas: tulang utuh dipecah menjadi dua, pukulan diarahkan pada bagian diaphisys atau mesial (bagian tengah) tulang. Setelah itu salah satu bagian ephipisys (proximal atau distal) tulang diambil dan dilakukan pangkasan untuk membentuk tajaman sesuai keinginan. Pukulan diarahkan ditengah tulang dengan sudut kemiringan tertentu ke arah berlawanan dengan bagian ephipisys. Alat tulang yang dihasilkan melalui teknik ini sebanyak 11 spesimen.

3. Pecah, tekan, pangkas, dan gosok: tulang utuh dipecah menjadi dua, pukulan diarahkan pada bagian diaphisys atau mesial (bagian tengah) tulang. Kemudian dilakukan tekanan pada bagian pecahan tulang hingga didapatkan bagian yang terlepas dari tulang intinya. Selanjutnya dilakukan pangkasan untuk membentuk tajaman dan akhirnya dilakukan penggosokan untuk menghaluskan tajaman.alat yang dihasilkan melalui teknik ini adalah spesimen nomor 25.

4. Pecah, pangkas, belah, dan gosok: tulang utuh dipecah menjadi dua, pukulan diarahkan pada bagian diaphisys atau mesial (bagian tengah) tulang. Kemudian dilakukan pangkasan untuk membuang 
bagian ephipisysnya, setelah itu tulang dibelah secara vertikal untuk mendapatkan bagian tulang yang pipih, selanjutntnya dilakukan pembuatan tajaman dengan cara pemangkasan dan penggosokan untuk menghaluskan tajaman. Alat tulang yang dihasilkan melalui teknik ini adalah spesimen nomor 21 dan nomor 25.

Alat tulang yang memperlihatkan jejak pemakaian yaitu spesimen nomor 8, 13, dan 21. Spesimen nomor 8 berupa lancipan yang terbuat dari tulang kering (tibia) bos sp.(sapi). Spesimen nomor 13 berupa lancipan yang terbuat dari tanduk (antler) cervus hippelaphus (rusa). Spesimen nomor 21 berupa spatulal pisau yang terbuat dari tulang kaki bovidae.

\section{Tipologi alat tulang Situs Sangiran}

Tipologi alat tulang diketahui berdasarkan penggabung antara morfologi, ciri teknologi (letak dan bentuk tajaman), dan jejak pakai. Analisis morfologi telah dilakukan untuk mengetahui bentuk umum artefak bardasarkan penampangnya, apakah berbentuk cembung, cekung, pipih, segitiga, elips, lonjong, persegi, dan sebagainya. Selain itu pengamatan juga ditujukan untuk mengetahui bentuk khusus berdasarkan ciri spesifik artefak yang terlihat pada bidang atas (dorsal), profil, bidang bawah (ventral), irisan, bagian distal, median, proksimal, maupun sisi lateral kiri dan kanan. Pengukuran dilakukan terhadap matriks artefak yang mengacu pada panjang, lebar, dan tebal pada bagian proksimal, median, dan distal, serta sudut kelerengan tajaman.

Berdasarkan bentuk dan letak tajaman spesimen yang kami teliti, terdapat 4 jenis alat tulang di Situs Sangiran yaitu: pisau sebanyak 2 atau 3 buah, lancipan 19 buah, spatula 8 atau 9 buah, dan sebuah kapak perimbas (chopper). Selain itu terdapat sebuah variasi dari lancipan yaitu lancipan berujung ganda (spesimen no. 20). Spesimen nomor 21 masih belum diketahui teknologi pembuatannya, dari segi bentuk tajaman pipih dan melebar maka alat ini adalah spatula. Tetapi terdapat kilapan atau bagian yang halus pada tajamannya kemungkinan bekas pemakaian. "kedua sisi tajamannya bersentuhan dengan sesuatu, sihingga menghasilkan jejak kilapan yang simetris pada tajamannya".

\section{Kronologi alat tulang Situs Sangiran}

Informasi stratigrafi dibutuhkan untuk mengetahui umur sehingga bisa dibuatkan kronologi alat tulang Situs Sangiran. Pengamatan terhadap jenis lapisan yang masih menempel pada fosil dilakukan terhadap sampel yang tidak memiliki informasi lokasi penemuan dan lapisan tanah. Untuk sampel seperti ini hanya bisa memberikan informasi lapisan tanah, lokasi penemuannya tidak bisa diketahui.

Dari ke 33 sampel yang penulis amati terdapat 11 spesimen yang tidak diketahui posisi stratigrafisnya. Sementara 14 spesimen diketahuiposisi stratigrafisnya melalui pengamatan sisa lapisan tanah yang masih melekat pada permukaannya. Lima spesimen diketahui posisi stratigrafisnya melalui informasi pustaka (nomor 3 dan 26 dari penggalian), dan 3 spesimen diketahui posisi stratigrafisnya dari hasil penggalian yaitu nomor 7,24 , dan 25.

Pembacaan posisi stratigrafi sampel alat tulang yang penulis amati, yaitu: alat tulang muncul pertama kali di Situs Sangiran pada sekitar 900.000 tahun yang lalu pada saat terbentuknya lapisan Grenzbank, eksis pada masa terbentuknya lapisan Kabuh dan terus eksis hingga sekitar 250.000 tahun yang lalu pada saat terbentuknya lapisan 


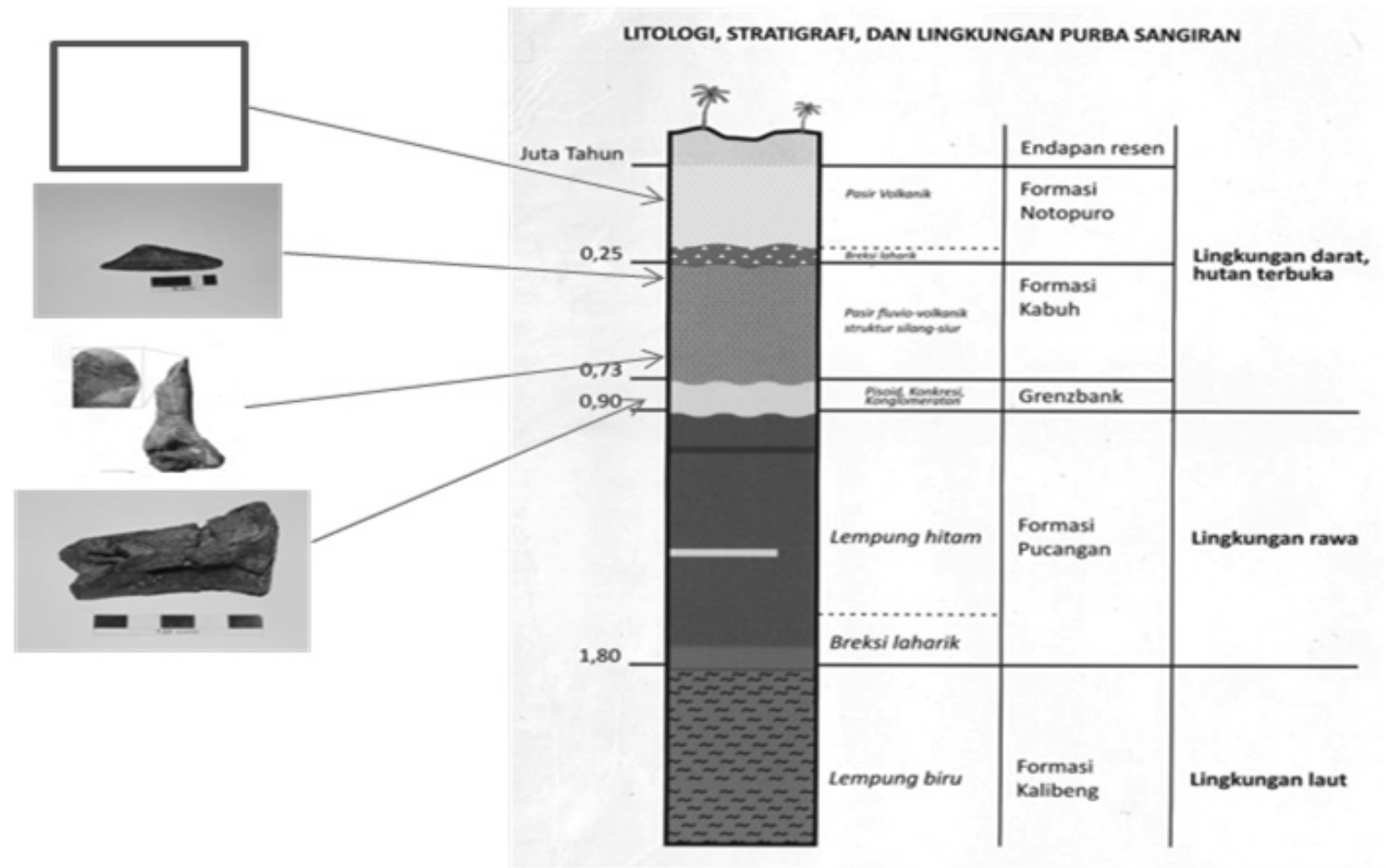

\section{PosisistratigrafialattulangdiSitusSangiran}

Notopuro. Dua spesimen berasosiasi dengan Grenzbank, satu spesimen berasosiasi dengan Notopuro, dan 18 spesimen berkonteks Kabuh.

\section{Sebaran alat tulang di Situs Sangiran}

Identifikasi sebaran berguna untuk memastikan keberadaan alat tulang di Situs Sangiran. Meskipun jumlah temuan sedikit, tetapi kalau ditemukan pada lokasi yang cukup luas berarti keberadaannya cukup meyakinkan. Alat tulang di Situs Sangiran ditemukan di sekitar Desa Ngebung (Ngebung, Gunung Kelir Padas, Sendang Klampok, Triangulasi, Kluster di Grasak), Desa Cangkol (Blimbing dan Tapan), Desa Manyarejo

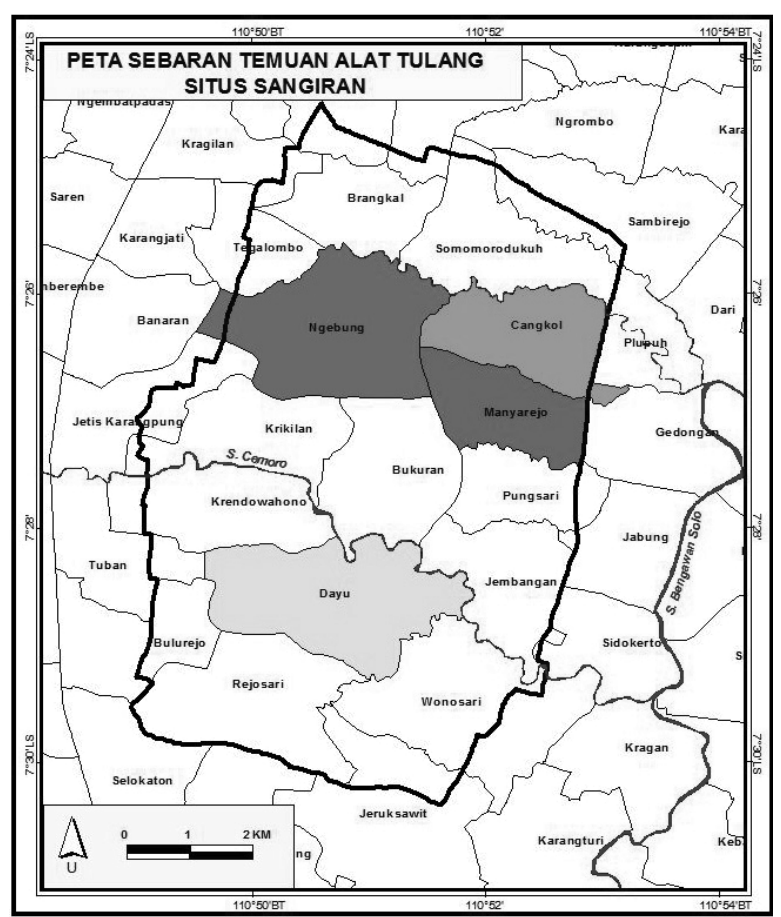
(Grogolan Wetan), Desa Dayu (Tanjung, Dayu, dan Pucung). 


\section{PENUTUP}

Homo erectus di Situs Sangiran telah membuat dan memakai alat tulang sejak sekitar 900.000 hingga 100.000 tahun yang lalu. Mereka menggunakan teknik pecah, teknik pangkas, teknik belah, dan penggosokan, serta gabungan teknik-teknik itu dalam membuat alat tulang. Alat yang mereka buat terdiri atas pisau, spatula, lancipan, dan variasi lancipan yaitu lancipan berujung ganda.

Bahan baku yang digunakan terdiri atas 12 jenis komponen anatomis binatang yaitu: 1. Tulang kering (tibia), 2. Tulang lengan atas (humerus), 3.Tulang paha (femur), 4. Tanduk (antler), 5. Telapak kaki depan (metacarpal), 6. Tulang hasta (radius), 7. Tulang rusuk (costae), 8. Tulang panjang, 9. Tulang kaki, dan 10. Tulang binatang, 11. Telapak kaki belakang, dan 12. Gading.

Jenis binatang yang digunakan sebagai bahan pembuatan alat tulang adalah cervus sp., cervus hippelaphus, sus sp., bos sp., rhinoceros, elephantidae, dan bovidae. Alat tulang di Situs Sangiran ditemukan di sekitar Desa Ngebung (Ngebung, Gunung Kelir Padas, Sendang Klampok, Triangulasi, Kluster di Grasak), sekitar Desa Cangkol (Blimbing dan Tapan), Desa Manyarejo (Grogolan Wetan), sekitar Desa Dayu (Tanjung, Dayu, dan Pucung). 


\section{DAFTAR PUSTAKA}

Abdullah, Ilham. 2013. Alat Tulang dari Situs Sangiran: Bahan Baku, Teknologi, Tipologi, Kronologi, dan Sebarannya dalam Jurnal Sangiran, Balai Pelestarian Situs Manusia Purba Sangiran, Vol. 2.

Anonim. 2011. Laporan Peninjauan Kepurbakalaan di Kecamatan Bringin, Kabupaten Ngawi, Jawa Timur. Balai Arkeologi Yogyakarta.

Anonim. 2013. Laporan Kajian Potensi Cagar Budaya DAS Bengawan Solo. Balai Pelestarian Situs Manusia Purba Sangiran.

Budiman, dkk. 2011. Temuan Fosil Sisa Fauna Dari Situs Grogolan Wetan: Determinasi dan Konteks Stratigrafi dalam Kehidupan Purba Sangiran. Pusat Penelitian dan Pengembangan Arkeologi Nasional.

Kusno, Abi. 2006. Pemanfaatan Bovidae di Situs Song Terus Punung Jawa Timur, Skripsi. Jurusan Arkeologi, Fakultas IImu Budaya, Universitas Indonesia.

Nugraha, S. dan Hidayat, M. 2011. Eksplorasi Situs Sangiran: Penelitian Situs Tanjung. Balai Pelestarian Situs Manusia Purba Sangiran.

Prasetyo, B. 2011. Peneliti dan Penelitian di Sangiran dalam Kehidupan Purba Sangiran. Pusat Penelitian dan Pengembangan Arkeologi Nasional.

Sari, M. A. P. 2012. Bentuk Bidang Pecahan Fosil Cervidae Koleksi Museum Sangiran (Analisis Mikroskopis), Skripsi. Jurusan Arkeologi, Fakultas IImu Budaya, Universitas Gadjah Mada.

Widianto, Harry. dkk. 1997. Penelitian Situs Sangiran: Proses Sedimentasi, Posisi Stratigrafi dan Kronologi Artefak pada Endapan Purba Seri Kabuh dan Seri Notopuro. Berita Penelitian Arkeologi 01. Balai Arkeologi Yogyakarta.

Widianto, Harry dan Noerwidi S. 2009. Atlas Prasejarah Indonesia. Jakarta: Direktorat Geografi Sejarah.

Widianto, Harry dan Simanjuntak, Harry T. 2009. Sangiran Menjawab Dunia. Balai Pelestarian Situs Manusia Purba Sangiran.

Yuwono, J. S. E. 2009. Pengadaan Peta Digital Tataguna Lahan Situs Sangiran. Laporan. Balai Pelestarian Situs Manusia Purba Sangiran. 